\title{
COMPARATIVE EVALUATION OF ELISA AND RAPID SCREENING TECHNIQUES FOR THE DIAGNOSIS OF HCV IN HAEMODIALYSIS PATIENTS IN TERTIARY CARE HOSPITAL, SOUTH BIHAR, INDIA
}

\author{
Maheshwar Narayan Singh ${ }^{1}$, Arjun Lal2, Chandan Kumar Poddar³, Syed Khursheed Ejaz ${ }^{4}$ \\ 1 Professor, Department of Microbiology, Anugrah Narayan Magadh Medical College, Gaya. \\ ${ }^{2}$ Associate Professor, Department of Microbiology, Anugrah Narayan Magadh Medical College, Gaya. \\ ${ }^{3}$ Research Scholar, Department of Microbiology, Indira Gandhi Institute of Medical Sciences, Patna. \\ ${ }_{4}^{4}$ Assistant Professor, Department of Biochemistry, Narayan Medical College and Hospital, Sasaram.
}

\section{BACKGROUND}

ABSTRACT

Globally, Hepatitis C virus (HCV) infection became one of the major health problems. Mainly HCV infection attacks the liver and can cause chronic hepatitis, liver cirrhosis (27\%) and liver cancer $(25 \%)$ and shows significant mortality and morbidity. Worldwide, approximately $2 \%$ - 3\% (around 170 million) of population was chronically infected with HCV. Hence, every year more than $5,00,000$ people die with HCV related complications. According to WHO safe blood is a universal right, which means blood that is fully screened and harmless to the recipient and is not contaminated with any blood-borne pathogenic diseases such as HIV, HCV and HBV.

In this study, comparative evaluation was made of ELISA and Rapid Screening Techniques for the Diagnosis of HCV in Haemodialysis patients in a tertiary care hospital, South Bihar, India.

\section{MATERIALS AND METHODS}

Study Design- A cross-sectional study was carried out in all aged patients on haemodialysis disease attending the OPD, tertiary care hospital in Gaya (Bihar), India, after obtaining Institutional Ethics Committee approval over a period of two years from May 2015 to May 2017. All the consecutive patients during the study period who were all aged and gave written informed consent were included in the study. Age, gender and clinical history of the patients were recorded in the case record form after written informed consent.

\section{RESULTS}

A total of 800 blood samples from patients in the Department of Microbiology and Haemodialysis Centre of Anugrah Narayan Magadh Medical College, Gaya, Bihar and Associated Hospital of Bihar were screened for anti-HCV antibody. The overall prevalence of HCV was found to be $2.5 \%$. The mean age of infected patients in the study group was $37.7 \pm 1.32$ years (range 19 to 76 years). Of the 800 samples tested, 2.75\% were positive for HCV by ELISA test and 2.5\% were positive by Rapid test [Table 2] [Chart 2]. Considering the results of HCV ELISA test, the sensitivity, specificity, PPV and NPV of ELISA were 95.65\%, 99.74\%, 91.67\% and 99.87\% respectively. The sensitivity, specificity, PPV and NPV of Rapid test were 95.24\%, 99.74\%, 90.90\% and 99.87\% respectively.

\section{CONCLUSION}

In conclusion in the present study the sensitivity, specificity, PPV and NPV of ELISA were 95.65\%, 99.74\%, 91.67\% and 99.87\% respectively. The sensitivity, specificity, PPV and NPV of Rapid test were 95.24\%, 99.74\%, 90.90\% and 99.87\% respectively. An ideal rapid test is a boon in time-saving situations like dialysis. Since HCV screening by a rapid test is easier, time saving, can be easily performed by any trained health care worker at any time of need, it can definitely be preferred as a screening test not only before haemodialysis but also for any other emergency surgery. It is cost effective also.

\section{KEYWORDS}

Hepatitis C Virus (HCV), Immunochromatographic Test Kit (ICT), ELISA, Haemodialysis, Chronic Kidney Disease.

HOW TO CITE THIS ARTICLE: Singh MN, Lal A, Poddar CK, et al. Comparative evaluation of ELISA and rapid screening techniques for the diagnosis of HCV in haemodialysis patients in tertiary care hospital, South Bihar, India. J. Evolution Med. Dent. Sci. 2017;6(93):6683-6687, DOI: 10.14260/jemds/2017/1448

\section{BACKGROUND}

Globally, Hepatitis C virus (HCV) infection became one of the major health problems. ${ }^{1}$ Mainly HCV infection attacks the liver and can cause chronic Hepatitis, liver cirrhosis $(27 \%)$ and liver cancer (25\%) and shows significant mortality and

'Financial or Other Competing Interest': None.

Submission 25-10-2017, Peer Review 21-11-2017,

Acceptance 28-11-2017, Published 11-12-2017.

Corresponding Author:

Dr. Chandan Kumar Poddar,

Research Scholar,

Department of Microbiology,

IGIMS, Patna.

E-mail: chandan_microbiology@yahoo.co.in

DOI: $10.14260 /$ jemds $/ 2017 / 1448$

morbidity. Worldwide, approximately $2 \%-3 \%$ (around 170 million) of population was chronically infected with HCV. Hence, every year more than $5,00,000$ people die with HCV related complications. ${ }^{2} \mathrm{HCV}$ is a blood-borne virus. The transmission of HCV infection mainly occurs among drug users (sharing of injection equipment), re-use or inadequate sterilisation of medical equipment like needles and syringes, transfusion of unscreened blood and blood products. HCV can also be transmitted by parental transmission infected mother to child) and sexual contact; however, these modes of transmission are much less common. ${ }^{3,4}$

Infection with Hepatitis $\mathrm{C}$ virus (HCV) has been identified as the major cause of post-transfusion non-A and non- $\mathrm{B}$ hepatitis. ${ }^{5}$ The prevalence of HCV is consistently higher 
among haemodialysis patients than in general population and has been associated with greater morbidity and mortality. ${ }^{6}$ The high prevalence of HCV infection in haemodialysis patients has been attributed not only to the frequency of blood transfusion, but also to increasing years on dialysis suggesting that HCV may be transmitted among patients in the dialysis unit, probably as a result of poor infection control practices. ${ }^{7}$

Every year millions of lives are saved due to the blood transfusion and with every unit of blood there is $1 \%$ chance of Transfusion Transmissible Infections (TTI's). According to WHO safe blood is a universal right, which means blood that is fully screened and harmless to the recipient and is not contaminated with any blood-borne pathogenic diseases such as HIV, HCV and HBV. So, WHO made it mandatory to screen pre-transfusion blood for all blood transfusion associated diseases. In India, screening of each and every blood units are mandatory and it is routinely done in blood banks. Screening and confirmation of HCV infection is based on advanced molecular and immunological techniques. For these screening techniques, they require well established lab, expensive instruments and well-trained technicians. Because this is expensive, blood banks use rapid immunochromatographic test (ICT) kits to screen HCV in blood donors. ${ }^{8,9}$ This is a comparative evaluation of ELISA and Rapid Screening Techniques for the Diagnosis of HCV in Haemodialysis patients in a tertiary care hospital, South Bihar, India.

Chronic kidney disease (CKD) was included among NonCommunicable Diseases (NCD) in 2011 by World Health Organisation. HCV is linked to CKD in several ways. Some forms of renal disease are precipitated by HCV and End-Stage Renal Disease [ESRD] patients are at rising risk of HCV acquisition. Nowadays, the spread of HCV among dialysis patients is declining, but its prevalence remains high mainly in developing countries. Periodic screening of HCV infection is mandatory to prevent newer transmission and there is a need of effective diagnostic method in high resource regions. With this background, this study was done.

\section{MATERIALS AND METHODS}

\section{Sample Size}

A total of 800 blood samples from patients on haemodialysis were collected.

\section{Place of Study}

Patients attending the Department of Microbiology, Anugrah Narayan Magadh Medical College, Gaya, Bihar and Associated Hospital of Bihar between May 2015 and April 2017.

\section{Study Design}

A cross-sectional study was carried out in patients of all ages on haemodialysis attending the OPD, tertiary care hospital in Gaya (Bihar) India after obtaining Institutional Ethics Committee approval over a period of two years. All the consecutive patients during the study period of all ages, who gave written informed consent were included in the study. Age, gender and clinical history of the patient were recorded in the case record form after written informed consent.

\section{Period of Study}

Two years.

\section{Inclusion Criteria}

The patients with HCV infection attacks the liver causing chronic hepatitis, liver cirrhosis and liver cancer in patients of all age groups were included in the study.

\section{Exclusion Criteria}

Pregnant women and acute renal failure cases were excluded.

\section{Consent}

Written consent from patients of all age groups.

\section{Collection and Transport of Specimen}

$5 \mathrm{~mL}$ of Fresh whole blood was collected from each patient at the Department of Microbiology and Haemodialysis Centre of Anugrah Narayan Magadh Medical College, Gaya, Bihar and Associated Hospital of Bihar in sterile blood collection tubes pre-treated with EDTA. Serum was obtained after centrifugation. Serological test was performed according to WHO recommendation involving rapid diagnostics assays and ELISA. Sera were tested for anti-HCV antibodies by rapid ICT immediately (Span Diagnostics Ltd. India). Sera were stored at $-20^{\circ} \mathrm{C}$ and further tested by third generation ELISA (ERBA Lisa Hepatitis C, TRANSASIA BIO-MEDICALS LTD. B-11, OIDC, DAMAN-396210)) as per the manufacturer's instructions.

\section{Statistical Analysis}

The X2 (Chi-square) test and analysis using the statistical software (SPSS version 18) was performed for quantitative variables to check for relationship in detecting HCV infection. Percentages were calculated directly for HCV infection. $\mathrm{P}=$ 0.05 was used as the accepted significance level. Performance of rapid ICT kits was evaluated in terms of sensitivity, specificity, positive predictive value (PPV), negative predictive value (NPV) and efficiency which can be defined as follows: Sensitivity $=[\mathrm{TP} /(\mathrm{TP}+\mathrm{FN})] \mathrm{X} 100$, Specificity $=[\mathrm{TN} /$ $(\mathrm{TN}+\mathrm{FP})] \mathrm{X} 100$, Positive Predictive Value $(\mathrm{PPV})=[\mathrm{TP} /$ $(\mathrm{TP}+\mathrm{FP})] \mathrm{X} 100$, Negative Predictive Value $(\mathrm{NPV})=[\mathrm{TN} /$ $(\mathrm{TN}+\mathrm{FN})] \mathrm{X} 100$, Efficiency $=[(\mathrm{TP}+\mathrm{TN}) /(\mathrm{TP}+\mathrm{FN}+\mathrm{TN}+\mathrm{FP})] \mathrm{X}$ 100].

\begin{tabular}{|c|c|c|c|c|}
\hline $\begin{array}{c}\text { Age } \\
\text { Group }\end{array}$ & $\begin{array}{c}\text { Negative } \\
\text { No. }\end{array}$ & $\begin{array}{c}\text { Positive } \\
(\%)\end{array}$ & Total (\%) & \multirow{10}{*}{$\begin{array}{c}\text { P-Value } \\
\text { Calculation } \\
\text { Chi-square= } \\
11.6119 \\
\text { p-value= } \\
0.008838 \\
\text { p-value is } \\
\text { less than } \\
0.05\end{array}$} \\
\hline $19-30$ & 117 & $\begin{array}{c}08 \\
(40 \%)\end{array}$ & $\begin{array}{c}125 \\
(15.63 \%)\end{array}$ & \\
\hline $31-45$ & 336 & $\begin{array}{c}09 \\
(45 \%)\end{array}$ & $\begin{array}{c}345 \\
(43.13 \%)\end{array}$ & \\
\hline $46-60$ & 283 & $\begin{array}{c}02 \\
(10 \%) \\
\end{array}$ & $\begin{array}{c}285 \\
(35.63 \%)\end{array}$ & \\
\hline $61-75$ & 44 & $\begin{array}{c}01 \\
(0.5 \%)\end{array}$ & $\begin{array}{c}45 \\
(05.63 \%)\end{array}$ & \\
\hline Overall & 780 & $\begin{array}{c}20 \\
(2.5 \%)\end{array}$ & $800(100)$ & \\
\hline $\begin{array}{c}\text { Age } \\
\text { Group }\end{array}$ & $\begin{array}{c}\text { Negative } \\
\text { (\%) }\end{array}$ & $\begin{array}{c}\text { Positive } \\
\text { (\%) }\end{array}$ & Total (\%) & \\
\hline Male & 718 & $\begin{array}{c}12 \\
(60 \%)\end{array}$ & $\begin{array}{c}730 \\
(91.25 \%)\end{array}$ & \\
\hline Female & 62 & $8(40 \%)$ & $\begin{array}{c}70 \\
(08.75 \%)\end{array}$ & \\
\hline Overall & 780 & $\begin{array}{c}20 \\
(2.5 \%)\end{array}$ & $800(100)$ & \\
\hline
\end{tabular}




\begin{tabular}{|c|c|c|c|c|}
\hline $\begin{array}{c}\text { Age } \\
\text { Group }\end{array}$ & $\begin{array}{l}\text { Replaceme } \\
\text { nt Donors }\end{array}$ & $\begin{array}{l}\text { Voluntar } \\
\text { y Donors }\end{array}$ & $\begin{array}{l}\text { Total } \\
(\%)\end{array}$ & \multirow{5}{*}{$\begin{array}{c}\text { P-value } \\
\text { Calculation } \\
\text { Chi- } \\
\text { square= } \\
0.5392 \\
\text { p-value= } \\
0.910207 \\
\text { p-value is } \\
\text { not less } \\
\text { than } 0.05\end{array}$} \\
\hline $19-30$ & 95 & 30 & $\begin{array}{c}125 \\
(15.63 \%) \\
\end{array}$ & \\
\hline $31-45$ & 260 & 85 & $\begin{array}{c}345 \\
(43.13 \%)\end{array}$ & \\
\hline $46-60$ & 210 & 75 & $\begin{array}{c}285 \\
(35.63 \%)\end{array}$ & \\
\hline 61-75 & 35 & 10 & $\begin{array}{c}45 \\
(05.63 \%) \\
\end{array}$ & \\
\hline Overall & 600 & 200 & $\begin{array}{c}800 \\
(100)\end{array}$ & \\
\hline & $\begin{array}{l}\text { 1a. Age } \\
\text { cemen }\end{array}$ & ס & $\begin{array}{l}\text { of Pat } \\
\text { ntary L }\end{array}$ & $\begin{array}{l}\text { s in } \\
\text { ors }\end{array}$ \\
\hline
\end{tabular}

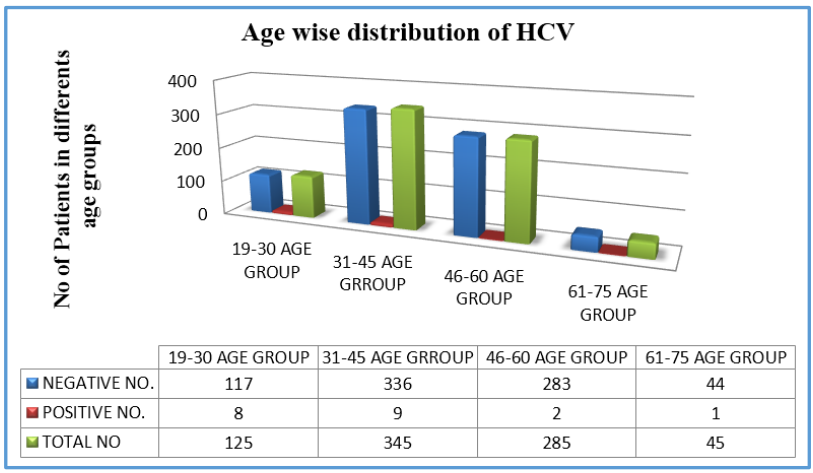

Chart 1. Age Wise Distribution of HCV Positive Test

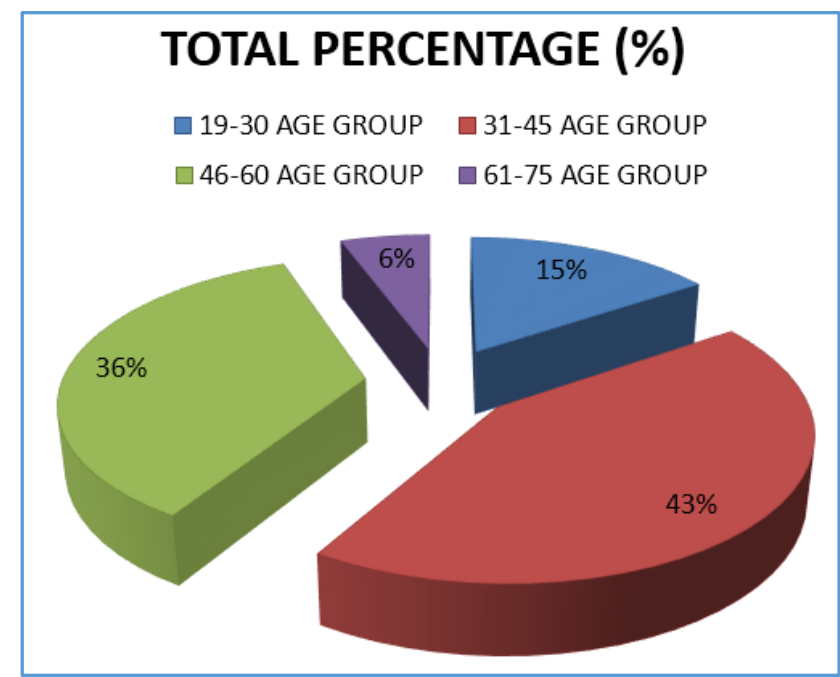

\begin{tabular}{|c|c|c|}
\hline Test (n= 800) & Positive & Negative \\
\hline ELISA HCV & $22(2.75 \%)$ & 778 \\
\hline Rapid Hepacard & $20(2.5 \%)$ & 780 \\
\hline Table 2. Comparison & of & (SL \\
\hline
\end{tabular}

Table 2. Comparison of ELISA Results with Rapid Test

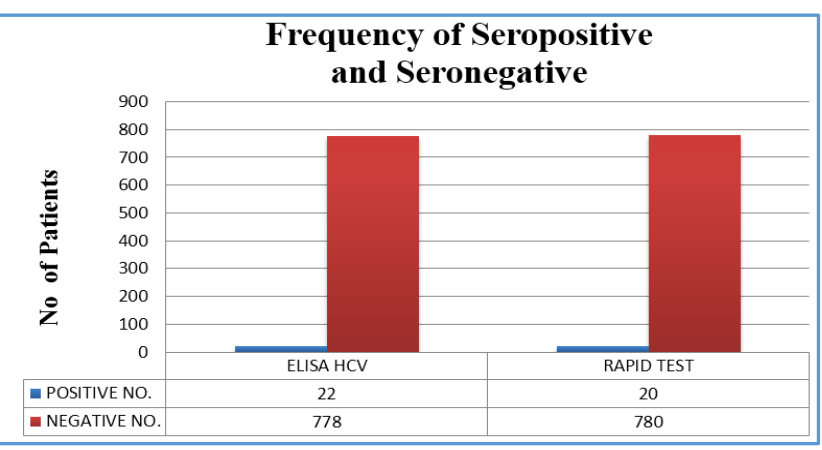

Chart 2. Frequency of Seropositivity and Seronegativity

Graph 1. Percentage of Age Groups according to the different Methods used for HCV Detection

\begin{tabular}{|c|c|c|c|c|c|c|}
\hline \multirow[b]{2}{*}{$\begin{array}{l}\text { Age } \\
\text { Group }\end{array}$} & \multicolumn{2}{|c|}{ Negative No. } & \multicolumn{2}{|c|}{ Positive (\%) } & \multirow[b]{2}{*}{ Total (\%) } & \multirow{6}{*}{$\begin{array}{c}\text { P-Value Calculation } \\
\text { Chi-square }=20.5484 \\
\mathrm{p}=.002211 \\
\mathrm{p} \text {-value is less } \\
\text { than } .05\end{array}$} \\
\hline & $\begin{array}{c}\text { (Rapid } \\
\text { Test) }\end{array}$ & $\begin{array}{c}\text { (ELISA } \\
\text { Test) } \\
\end{array}$ & $\begin{array}{c}\text { (Rapid } \\
\text { Test) }\end{array}$ & $\begin{array}{c}\text { (ELISA } \\
\text { Test) }\end{array}$ & & \\
\hline $19-30$ & 117 & 117 & $08(40 \%)$ & $8(36.36)$ & $125(15.63 \%)$ & \\
\hline $31-45$ & 336 & 335 & $09(45 \%)$ & $10(45.45)$ & $345(43.13 \%)$ & \\
\hline $46-60$ & 283 & 283 & $02(10 \%)$ & $2(9.09)$ & $285(35.63 \%)$ & \\
\hline $61-75$ & 44 & 43 & $01(0.5 \%)$ & $2(9.09)$ & $45(05.63 \%)$ & \\
\hline Overall & 780 & 778 & $20(2.5 \%)$ & $22(2.75 \%)$ & $800(100)$ & \\
\hline
\end{tabular}

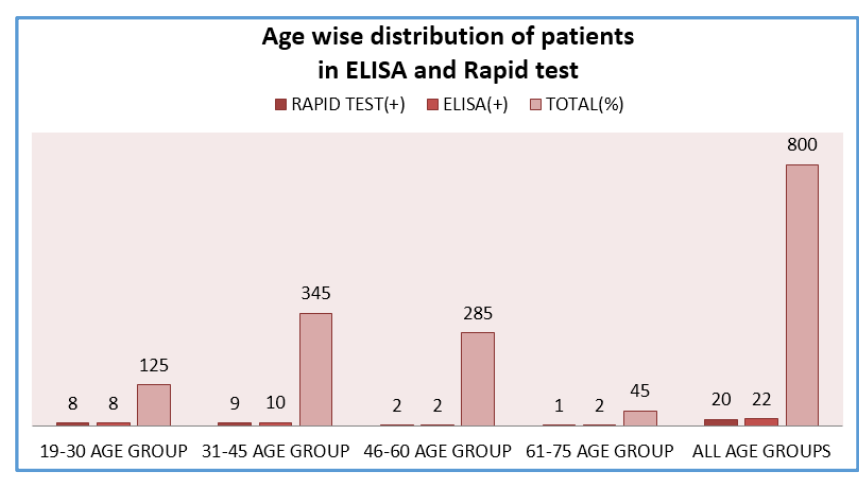

Chart 3. Age Wise Distribution of Patients of ELISA and Rapid Test

\begin{tabular}{|c|c|c|}
\hline & $\begin{array}{c}\text { HCV } \\
\text { ELISA (\%) }\end{array}$ & $\begin{array}{c}\text { One-Step } \\
\text { Rapid Test (\%) }\end{array}$ \\
\hline Sensitivity & $95.65 \%$ & $95.24 \%$ \\
\hline Specificity & $99.74 \%$ & $99.74 \%$ \\
\hline $\begin{array}{c}\text { Positive Predictive } \\
\text { Value (PPV) }\end{array}$ & $91.67 \%$ & $90.90 \%$ \\
\hline $\begin{array}{c}\text { Negative Predictive } \\
\text { Value (NPV) }\end{array}$ & $99.87 \%$ & $99.87 \%$ \\
\hline
\end{tabular}

Table 4. Sensitivity Comparison of ELISA and Rapid Screening Techniques for the Detection of HCV among Haemodialysis Patients when ELISA was taken as Gold Standard

\section{RESULTS}

A total of 800 blood samples from patients in the Department of Microbiology and Haemodialysis Centre of Anugrah Narayan Magadh Medical College, Gaya, Bihar and Associated Hospital of Bihar were screened for anti-HCV antibody. The overall prevalence of $\mathrm{HCV}$ was found to be $2.5 \%$. The mean 
age of infected patients in the study group was $37.7 \pm 1.32$ years (range 19 to 76 years). Seven hundred and Thirty $(91.25 \%)$ were male and Seventy $(08.75 \%)$ were female. The replacement donors were $600(75 \%)$ and voluntary donors were $200(25 \%)$ as per [Table 1a]. The positivity amongst the male population was $60 \%$ which was higher than the female population $40 \%$, but the difference was statistically significant $(\mathrm{p}=0.05)$ [Table 1] [Graph 1] [Chart 1].

Anti-HCV antibodies were positive in $20(2.5 \%)$ patients by ICT method, while $22(2.75 \%)$ patients were positive by ELISA method [Table 2] [Charts 2]. There was statistical significance between ICT and ELISA methods for HCV detection. Eight females were positive by both methods. Remaining 62 samples were negative by both ICT and ELISA methods. Anti-HCV antibodies were negative at extremes of age such as below 19 years and above 75 years. The prevalence of ELISA in HCV infection among haemodialysis patients in this study was $2.75 \%$ [Table 2] [Charts 2].

In the 19 - 45 years' age group 17 (85\%) were positive by ICT and 18 (81.81\%) were positive by ELISA, while among 46 - 75 years, $3(15 \%)$ were positive by ICT and $4(18.18 \%)$ were positive by ELISA (Table 3) (Charts 3).

Of the 800 samples tested, $2.75 \%$ were positive for HCV by ELISA Test and $2.5 \%$ were positive by Rapid test [Table 2] [Chart 2]. Considering the results of HCV ELISA test, the sensitivity, specificity, PPV and NPV of ELISA were 95.65\%, 99.74\%, 91.67\% and 99.87\% respectively. The sensitivity, specificity, PPV and NPV of Rapid test were 95.24\%, $99.74 \%$, $90.90 \%$ and $99.87 \%$ respectively (Table 4 ).

\section{DISCUSSION}

In the present study, the number of male donors 730 $(91.25 \%)$ were more than the number of female donors 70 (8.75\%). Similar findings were observed by Rose et al and Singh K et al.10,11 The present study showed that majority of donors were replacement donors 600 (75\%), while voluntary donors were $200(25 \%)$ which is similar to the other studies done. ${ }^{11,12}$ In India replacement donors constitute a major group of blood donors, which is reflecting the lack of awareness in the general population. ${ }^{4}$

It is well known that haemodialysis patients are at high risk for development of HCV infection. The prevalence of HCV infection varies greatly among various patients on haemodialysis from different geographic regions. However, the data on the prevalence of anti-HCV among Indian haemodialysis patients remain scanty. In the present study, the prevalence of HCV infection among haemodialysis patients was found to be $2.75 \%$. This is in accordance with other studies, where the prevalence of HCV was $5.9 \%$ and where the prevalence was $6.1 \% .^{13,14}$

Globally, detection and diagnosis of HCV infection are mainly based on immunological assays, among which rapid ICT kit and ELISA are most common and widespread methods. ${ }^{15}$ An important problem encountered at this point is the conflict between the results of two assays. This can be resolved depending on the availability of suitable kits. Generally, the sensitivity of the ELISA kits was good when compared to the rapid immunochromatographic test (ICT) kits. In terms of price the cost of ELISA kit was very high, whereas the cost of ICT kit for HCV antibody detection was much cheaper. The time needed for ELISA assay was more
On the other hand, by using ICT kits the screening of the specimens was done within 10 to 15 minutes only. So, because of this less expensive and easy to handle and rapid screening nature the rapid test kits became an alternative for ELISA in blood banks. ${ }^{16}$

Since the introduction of screening assays for HCV antibodies, major efforts had been made to increase the diagnostic accuracy of the assays. The major concern in using rapid ICT is their variable degree of sensitivity and specificity. An ideal rapid test would have a high degree of positive predictive value and low degree of false negative result. ${ }^{15}$ Out of the 800 samples, $20(2.5 \%)$ were detected by the rapid ICT for anti-HCV antibodies. In the present study, ELISA was considered as the gold standard to document HCV infection. Results of this study showed that the sensitivity of the rapid ICT kit was low (95.24\%) compared to the specificity, (99.74\%) positive predictive value $(90.90 \%)$ and negative predictive value $(99.87 \%)$, which were significantly high.

A high prevalence of HCV (21\%) co-infection and lower prevalence of chronic HBV infection (4.3\%) and HIV (1.8\%) co-infection were found among newly diagnosed patients with pulmonary TB in Georgia. The most prevalent HCV genotype among newly diagnosed patients with TB was type $1 \mathrm{~b}$ (45\%); HCV genotypes $2 \mathrm{a} / 2 \mathrm{c}, 2 \mathrm{a}$ and $3 \mathrm{a}$ were less common among patients with TB. We also found that prevalent HCV co-infection was independently associated with IDU, current smoking and HBV co-infection. 17-22

An additional positive sample detected by ELISA for HCV antibodies in the present study could be due to the short incubation period of the ICT. Characteristically, short incubation tests do not detect low affinity or low concentration of antibodies as compared to the classic type of immunoassays, which employ longer incubation time allowing reaction to proceed to completion. ${ }^{23}$ Few studies have examined the impact of HCV infection on incident hepatotoxicity during anti-TB treatment. ${ }^{17-23}$ There has been concern that underlying chronic liver disease caused by viral hepatitis increases the risk of first-line anti-TB drug-induced hepatotoxicity.

\section{CONCLUSION}

In conclusion in the present study the sensitivity, specificity, PPV and NPV of ELISA were 95.65\%, 99.74\%, 91.67\% and $99.87 \%$ respectively. The sensitivity, specificity, PPV and NPV of Rapid test were $95.24 \%, 99.74 \%, 90.90 \%$ and $99.87 \%$ respectively. An ideal rapid test is a boon in time-saving situations like dialysis. Since HCV screening by a rapid test is easier, time saving can be easily performed by any trained heath care worker at any time of need. It can definitely be preferred as a screening test not only before haemodialysis, but also for any other emergency surgery. It is cost effective also. Hence, we conclude that HCV screening can be preferably done by a rapid test followed by a supplemental ELISA and polymerase chain reaction.

\section{REFERENCES}

[1] Hanafiah KM, Groeger J, Flaxman AD, et al. Global epidemiology of hepatitis virus $\mathrm{C}$ infection: new estimates of age specific antibody to HCV seroprevalence. Hepatology 2013;57(4):1333-42. 
[2] Lee MH, Yang HI, Yuan Y, et al. Epidemiology and natural history of hepatitis C virus infection. World J Gastroenterol 2014;20(28):9270-80.

[3] Lozano R, Naghavi M, Foreman K, et al. Global and regional mortality from 235 causes of death for 20 age groups in 1990 and 2010: a systematic analysis for the Global Burden of Disease Study 2010. Lancet 2012;380(9859):2095-128.

[4] WHO. Hepatitis C. www.who.int/ mediacentre/factsheets/fs164/en/.

[5] Capner PM, Simmonds P, Peuthere JF. Togavirus and hepacivirus. In: Greenwood D, Slack R, Peutherer J, eds. Medical microbiology. 17th edn. Philadelphia: Churchill Livingstone 2007:524-35.

[6] Natov SN, Pereira BJ. Hepatitis C in dialysis patients. Adv Ren Replace Ther 1996;3(4):275-83.

[7] Quer J, Esteban JI. Epidemiology. In: Thomas H, Lemon S, Zuckerman A. eds. Viral Hepatitis. $3^{\text {rd }}$ edn. Australia: Blackwell Publishing 2005:407-25.

[8] Pyadala N, Maity SN. Seroprevalence of transfusion transmissible infections among blood donors attending in a rural teaching hospital at Sangareddy. Int J Biol Med Res 2015;6(4):5249-53.

[9] Guyton AC, Hall JE. Textbook of medical physiology. $11^{\text {th }}$ edn. Saunders 2008; p. 640.

[10] Rose D, Sudharsanam A, Padankatti T, et al. Increasing prevalence of HIV antibody among blood donors monitored over 9 years in blood donors monitored over 9 years in blood bank. Indian J Med Res 1998;108:42-4.

[11] Singh K, Bhat S, Shastry S. Trend in seroprevalence of Hepatitis B virus infection among blood donors of coastal Karnataka, India. J Infect Dev Ctries 2009;3(5): 376-9.

[12] Ahmad I, Mishra A, Poddar CK, et al. Sensitivity comparison of ELISA and rapid screening techniques for the detection of HBsAg among chronic liver disease (CLD) patients in a tertiary care hospital, south Bihar, India. J Evolution Med Dent Sci 2017;6(71):5045-9.

[13] Reddy GA, Dakshinamurthy KV, Neelaprasad P, et al. Prevalence of HBV and HCV dual infection in patients on haemodialysis. Indian J Med Microbiol 2005;23(1): 41-3.
[14] Almawi WY, Qadi AA, Tamim H, et al. Seroprevalence of hepatitis C Virus and Hepatitis B Virus among dialysis patients in Bahrain and Saudi Arabia. Transplant Proc 2004;36(6):1824-6.

[15] Khan JK, Lone DS, Hameed A, et al. Evaluation of the performance of two rapid immunochromatographic tests for detection of Hepatitis B surface antigen and anti HCV antibodies using ELISA tested samples. Sp Ed Ann 2010;16(1):84-7.

[16] Khansari N, Mazhari SZ, Rezvan H. A comparative study of a rapid test and ELISA for the serological determination of HIV infection. Acta Med Iran 1993;31:68-71.

[17] Chien JY, Huang RM, Wang JY, et al. Hepatitis C virus infection increases hepatitis risk during antituberculosis treatment. Int $\mathrm{J}$ Tuberc Lung Dis 2010;14(5):616-21.

[18] Ungo JR, Jones D, Ashkin D, et al. Antituberculosis drug-induced hepatotoxicity. The role of hepatitis $\mathrm{C}$ virus and the human immunodeficiency virus. Am J Respir Crit Care Med 1998;157(6 Pt 1):1871-6.

[19] Singh MN, Lal A, Poddar CK, et al. Efficacy of fineneedle aspiration technique, Ziehl-Neelsen stains and culture (BACTEC) in diagnosis of tuberculous lymphadenitis in tertiary care hospital, Gaya, India. J Evid Based Med Healthc 2017;4(70):4164-9.

[20] Ahmad I, Mishra A, Poddar CK, et al. Comparison of Ziehl-Neelsen stains with fine needle aspiration technique in diagnosis of tuberculous lymphadenitis in tertiary care hospital, South Bihar, India. J Evolution Med Dent Sci 2017;6(63):4598-602.

[21] Wang JY, Liu CH, Hu FC, et al. Risk factors of hepatitis during anti-tuberculous treatment and implications of hepatitis virus load. J Infect 2011;62(6):448-55.

[22] Kwon YS, Koh WJ, Suh GY, et al. Hepatitis C virus infection and hepatotoxicity during antituberculosis chemotherapy. Chest 2007;131(3):803-8.

[23] World Health Organization. Treatment of tuberculosis guidelines. $4^{\text {th }}$ edn. Geneva, Switzerland: WHO Press 2010. WHO/HTM/TB/2009.420 